\title{
1.1
}

\section{Crises: Principles and Policies \\ With an Application to the Euro Zone Crisis ${ }^{1}$}

Joseph E. Stiglitz

Economies around the world have faced repeated crises - more frequently over the past thirty years. ${ }^{2}$ The fact that they have become more frequent and pervasive at the same time that we believe we have learned more about the management of the economy and as markets have seemingly improved poses a puzzle: shouldn't rational markets avoid these catastrophes, the costs of which outweigh, by an enormous aniount, any benefit that might have accrued to the economy from the actions prior to the crisis that might have contributed to it? This is especially true of the large fraction of crises that can be called "debt crises," precipitated by a country's difficulty in repaying what it owes. The benefits of income smoothing (arising from the difference in the marginal utility of income in periods when income is low and when income is high) ate overwhelmed by the social and economic costs of the ensuing crisis.

For economic theory, crises pose another puzzle: typically the state variables that describe an economy change slowly. But what distinguishes a crisis is that the state of the economy seems to change dramatically, in a relatively short time. This should be even more puzzling to those who believe in some version of rational expectations, for shouldn't markets have anticipated the untoward change of events? And if they had done so, wouldn't the problems have appeared earlier? There is seldom any single item of "news" that leads to the kind of radical zevision of expectations that often seem to be associated with crises. ${ }^{3}$

For those who believe in well-functioning markets, there is yet another puzzle. The assets - the human, physical, and natural capital - of a country are essentially the same after the crisis as they were before. A misallocation of capital before the crisis - say as a result of a housing butble - should imply that incomes after the crisis would be lower than would otherwise be the case. But there is nothing in standard theory to suggest that there should be a high level of unemployment, of a dramatically lower tevel of output. Indeed, properiy measured, GDP might even increase. This is true even if there is a legacy of 
debt. Debt should affect the claims on society's resources, that is, how the national pie is divided; but that's all."

Keynesian economics provides some insights into these puzzles - certainly more than neoclassical models that assume that the economy is atways full employment. But standard Keynesian economics had little to say about dynamics: it was an equilibrium theory, attempting to explain the persistence of unemployment. It made no attempt to explain why the breaking of a bubble shotld have such adverse effects. Although modern variants of New Keynesian economics (originating with the work of Fisher ${ }^{5}$ that was contemporaneous with Keynes, and updated in the work of Greenwald and Stiglitz [1988a, 1988b, 1990, 1993a, 1993b) help explain why shocks to the economy that have significant effects on balance sheets would have persistent and long-lasting effects, ${ }^{6}$ they don't really explain crises - why ther should be events with large balance sheet effects - at least within a theor disciplined by some variant of rational expectations. (Of course, if we are willing simply to posit large changes in expectations and/or a change in asset prices unrelated to any change in underlying fundamentals, then it is easy to generate crises, especially of a kind associated with large changes in balance sheets.)

The euto crisis, and the Great Recession which led to it, provide dramatic instances of these puzzles. And a study of the unfolding euro crisis provides hints as to the plausibility of alternative explanations, and the strengths and deficiencies of different theories.

After providing a general theory of crises, in which multiple equilibrium and discontinuities in expectations play a critical role, we will then focus on the role of adjustments and the reasons that requisite adjustments sometimes don't occur.

\subsubsection{A theoretical taxonomy of crises}

Not all economic downtums are crises, but economic crises almost always become severe downturns, of varying durations. Broadly speaking, we can identify three categories of economic fluctuations:

(a) Short-term fluctuations, brought on by, for instance, excess inventory accumulations or central banks stepping on the brakes too hard in an overzealous fight against inflation. (Occasionally, short-term fluctuations can be brought on by a supply shock, such as a drought.)

(b) Somewhat deeper and longet-lasting downtums, the balance sheet recessions described earlier, often associated with the breaking of a bubble or the sudden realization that an important price (or set of prices) in the economy (such as the exchange rate) has been set "incorrectly," with consequences of a persistent (and evidentiy unsustainable) departure from "equilibrium." priot to the $2008 \mathrm{crisis}$, many economists had, for instance, argued that out-of-equilibrim exchange rates (sustained in part by government interventions) had led to global imbalances, and that a disorderly unwinding of these global imbalances would result in a crisis. ${ }^{7}$ As it turned out, it was the bursting of the housing bubble in the United States, rather than the global unwinding of global imbalances, that led to the crisis. ${ }^{8}$ Those crises associated with credit excesses (leading to bubbles) have become dubbed Minsky cycles. But while Minsky (see, for example, 1982) and Kindleberger (1978) have identified repeated patterns of credit excesses - often fueled by collateral-based lending, where, as real estate prices increases, the value of collateral on which lending is based also increases - it is hard to reconcile such excesses with rational expectations."

(c) Deep structural crises, such as the Great Depression, which seem to las far longer than can be accounted for by the slow process of repairing balance sheets. These arise out of the difficulties that market economies have in making large structural changes, which typically require significant investments in restoring the strength of those whose human and other capital has been eviscerated by the economic change; because of imperfections in capital markets (explicable in terms of information asymmetries) those who need to make these investments are constrained from doing so, and thus labor, which needs to be reallocated to reflect the structural change, is impeded from doing so. The breakdown of financial instifutions in the midst of these long-term downturns only serves to prolong them.

Identifying the nature of the crisis (or downtum) is not always easy, partially because a crisis of one type may morph into one of another type, partly because any long-lived crisis will have real balance sheet effects and will be because any long-lived crisis will have real balance sheet effects and will be
associated with problems in the financial sector - even when the financial sector was not the original cause of the crisis. There are strong reasons to believe that the downturn that began in 2008, the Great and Long Recession, is structural in nature. The fact that output fell in many countries in which there was no financial crisis (for instance, in manufacturing economies such as China) shows that it affected more than just the finance sector. The continuing weakness in the economy in the US, in the afternath of the 2008 crisis, where bank and corporate balance sheets have been largely restored fat least to the point that investment outside of real estate has returned to near-nomal levels ${ }^{13}$ ) suggests too that it is more than a balance sheet recession. ${ }^{12,13}$

This paper focuses on the latter two - and especially the third - kind of downturns, which are often deep and long lasting. 


\subsubsection{A general theoretical framework}

A crisis is a sudden change in the (perceived) state of the economy, one which is often associated with the collapse of a currency, the banking system, or the real economy. It is a sudden change in the performance of the economy. Standard models of the economy model the flow variables (consumption, investment, etc.) $\mathrm{x}$ as a function of a set of variables that describe the state of the economy, $S$, and a set of decision variables, $d$, which themselves are typically a function of an expanded set of state variables, which include expectations of the future. For simplicity, we write $\mathbf{d}=\mathbf{d}(\mathbf{S})$, so that the flow variables can be expressed simply as a function of the state of the economy. The state vatiables change according to a law of motion,

$$
\mathrm{dS} / \mathrm{dt}=\varphi(\mathrm{x}(\mathrm{S}), \mathrm{d}(\mathbf{S}), \mathbf{S})=\varphi^{*}(\mathbf{S})
$$

Because $S$ changes stows, $x$ and $d$ change slowly. There should be no crises. Occasionally, there are what may be viewed as exogenous changes that can lead to a sudden large change in the relevant variables. The above formulation should be generalized to include uncertainty; there can be an "outlier" reatization of a random variable (a drought), and, particularly in the presence of non-linearities, this can have a large impact on the state and behavior of the economy.

But most crises are not related to the realization of a 3 -standard deviation shock in an exogenous random variable. The $2008 \mathrm{crisis}$ was related to the real estate crash, the 2001 recession to the bursting of the tech bubbte. Both were endogenous disturbances. There were no large exogenous events that could have accounted for these crises,

Looking over past crises, there are four possible models that can describe the observed dynamics.

A. Multiple momentary equitibrium. Many economic models are characterized by multiple momentary equilibria. That is $s_{r}$ a given set of state variables maps not into a single set of flow variables, but into a multiplicity of possible equilibria. We may not (and typically do not) have a complete theory of determination of equilibrium: how one or the other members of the set happens to occur. For instance, if the "market" believes that a firm (an economy) is not likely to go bankrupt, interest rates will be low, and at the low interest rate, the probability of bankruptcy will be low. But if the market believes that the probability of bankuptcy is high, then there will be a high interest rate, and a correspondingly high probability of bankruptcy. Both of these can be rational expectations equilibria (see Greenwald and Stiglitz, 2003) ${ }^{\text {I4 }}$ The defining characteristic of such models is "positive feedbacks." With multiple momentary equilibria, the economy can move suddenly from one configuration into another - with the latter, for instance, having disastrous consequences for the economy or some group within the economy. To take up the example just given: if, suddenly, the market believes that there is a high probability of bankruptcy and interest rates (rationally) adjust to reflect this, then not only will the behavior of the economy change suddenly, but so will its evolttion. In short, there can be discontinuous changes in $x$ even if $S$ (now understood to include only the "real" physical variables like capital stock) changes slowly, and these discontinuous changes in $x$ can lead to discontinuities in the pattern of changes in $\$$. ( $\$$ may still be a continuous variahle, but $S(t)$ is not differentiable)

B. Expectations as State Variables. While physical objects (iike the capita stock) typically change continuously, this need not be the case for beliefs. And this includes beliefs about the future value of state variables. Since $\mathrm{d} S / \mathrm{dt}$ is not continuous when the economy changes from one momentary equilibritum to another, it is clearly conceivable that individuals (ever rationally) could suddenly change their beliefs abott the future course of the economy. For instance, if there are multiple momentary equilibria corresponding to every $\mathbf{S}(\mathrm{t})$, then as the economy "chooses" one or the other, the future course of the economy changes dramatically. This uncertainty can be rationally incorporated into beliefs ex ante ${ }^{15}$ Changes in the future course of the economy get reflected ${ }_{\text {r }}$ of course, in the values of assets, so that though the physical assets themselves change in a way which is continuous, the valuations themselves may change in ways which are discontinuous, leading to - and reinforcing - discontinuities in behavior.

The fact that in these and related models of dyramics expectations can play such a central role is consistent with the financial sector's emphasis on the role of confidence. If the market has confidence (for example, that there is only a low probability of default), then interest rates will be low as we have noted, and the probability of a default will be low. But such assertions do little to help explain (or affect) expectations, though sometimes they can be thought of as helping to construct sunspot equilibria, ${ }^{16}$ where certain government actions (like raising interest rates) serve as a coordinating mechanism on expectations (for example, that inflation will be low).

C. Multiple long-run equilibrium. Even if there is a unique momentary equilibrium, there can be multiple steady states, and the steady state to which the economy converges can (and will typically) depend on the initial conditions, $S_{0}$. Slight changes in these can lead to the convergence to a different equilibritum. Again, while $S$ is continuous, $\mathrm{d} S / \mathrm{dt}$ is not, and there can be sudden changes in the prospects of the economy as a result of a shock that moves the economy across a boundary. Debt can, for instance, go from being "sustainable" to being "unsustainable." 
Behaviors are likely to change discontinuously across these boundaries, so that $x(S)$ is not itsell continuous.

D. History matters: threshold effects and adjustment rigidities. The analysis so far has followed the standard macroeconomic tradition of treating the economy as described by a set of variables that described the physical state of the economy, say the amount of real and human capital. But in more general models, there is a richer set of state variables, including, for instance, the wealth (asset holdings) of each individual and each of their beliefs. Moreover, history matters. Their beliefs and actions are affected by the past in a way that is not adequately summarized by say current asset holdings. Formally, we can expand the set of state variables to include the values of asset holdings in prior periods, so that, say $\mathbf{x}_{t}=\varphi\left(\mathbf{S}_{\mathbf{t}}, \mathbf{S}_{\mathbf{t}-1}, \mathbf{S}_{\mathbf{t}-2}, \ldots.\right)$. History-dependent models include those in which individuals do not adjust behavior for small changes in $S$, for example, because of adjustment costs. Only when there are large disparities between the value of $x$ that would be chosen if there were no adjustment costs and the current value is large enough does $x$ change. The implication is that there can be discontinuities in $x$ even if, between this period and the last, there is a small change in $S$. The large change in $x$ can, of course, have large consequences for the future evolution of the economy: there can be a "crisis."

In this theory, then, crises are caused, in part, by rigidities in adjustment. If adjustment costs were lower, adjustments would be made smoothly, and the large discontinuities associated with crises would not occur. This was one of the arguments used for moving from fixed to flexible exchange rate systems: fixed exchange rate systerns result in cumulative disparities between the official exchange rate and the "shadow" exchange rate, what the exchange rate would have been in a free matket; adjustment must eventually occur, but the large adjustment that then occurs has far greater consequences than those that wotld have emerged from a series of smaller adjustments. (Interestingly, moving to a flexible exchange xate system has not elininated currency crises; if anything, they have become even more frequent. The destabilizing effects of untethered expectations, generating volatile short-term capital flows, often seems to overwhelm the adverse effects of discrete adjustment).

Similar discontintities in behavior atise when markets or government suddenly realize that some constraint (the ability to borrow, the ability to repay, the ability to support the currency, the ability to continute to grow without hitting some resource limitation) will be binding unless some large change in behavior occurs.

The discussion above focuses on large discontinutties in behavior that can arise even in the presence of the continuous movement in (physical) state variables, and even in the presence of rational expectations. "But there is overwhelming evidence that expectations are often not rational; it is hard to reconcile, for instance, behavior in the run up to the Great Recession with rational expectations. To be sure, as one would have expected, some market participants (such as investment bankers and hedge fund speculators) profitably exploited sorme of the irrationalities evidenced by other market participants, but hardly to the point of "correcting" the market. ${ }^{18}$ Still large numbers of individuats bought houses on the irrational belief that the housing bubble would continue, investors bought mortgages on the irrational belief that borrowers would and could repay the mortgages - in part because they too believed that the bubble would continue; and regulators lowered lending standards, even as the bubble's momentum gained force, again in the irrational belief that there was no bubble (because efficient markets would not tolerate a bubbie) and/or that one could not tell that there was a bubble until after it had broken broke (all policy is made under uncertainty, and, as housing prices soared, surely a rational regulator would have realized that there was a higher probability that there was a bubble). ${ }^{19}$ Later in this essay [ will provide further evidence that one cannot plansibly reconcite pre-crisis behaviour with rational expectations.

Once one admits the possibility of "irrational" expectations, then, of course, it is easy to generate crises, as market participants, acting in a herd-like manner, suddenly change their assessments of the future. Often, these reassessments are linked with the limited foresight of market participants - they can see perhaps one or two or at most three years down the road, but have a hard time tracing out longer-term dynamics. Thus, the Greek debt had been accumulating gradually. It did not go from suddenly becoming sustainable to being unsustainable. The revelation that it was slightly greater than had previously been thought may have helped precipitate the crisis, but the hidden debt was small, and was undertaken by a previous government, and so said nothing about the likely misbehavior of the government then in power. ${ }^{20}$

There are many other instances in which market participants suddenly realize that a posited path is not dynamically consistent, when it should have been obvious at an earlies stage that that was at least likely the case. In the US housing bubble, prices were rising far faster than incomes, so that the share of income that would have to be spent on housing would almost certainly increase, and would have to continue to increase if the bubble was to be sustained. But the demand for housing was sustained because of the high expected capital gains. Once it becane clear that housing prices couldr't continue to grow at the high rate that they had in the past, the demand for housing would fall, and housing prices risked coming down. The moment that this was commonly recognized, the bubble would break. Even acknowledging this fact says nothing about when the bubble would break. If large numbers believed that they were smarter than others, then they could believe that they could stay in the market until just before the bubble broke, earning excess returns in 
the interim. It was, of course, irrational for most matket participants to believe that they were smarter than "average."

Many of the circtmstances in which bubbles have burst, or in which a seeming persistent "disequilibrium" has finally unraveled, are associated with large market participants suddenly realizing that a constraint to which they had paid insufficient attention is about to bind in the not too distant future - for instance, an overvalued exchange rate cannot be sustained, once toreign exchange reserves are exhausted, and growth cannot continue at a rate greater than the increase in potential output (supply), once resources are fully utilized,

To be sure that one is not on an unsustainable path, one actually has to foresee infinitely far into the future. There can be paths that are dynamically efficient over any finite span of time but do not converge to the steady-state equilibrium (Hahn, 1966; Shell-Stiglitz, 1967). Standard equilibrium theory assumes markets exist infinitely far into the future - or that individuals behave as if there were such markets.

In short, there are a number of circumstances in which the dynamics of the economy appear to change discretely. There can be crises. But these models are typically markedly different from the models that have dominated macrow economic analysis in recent years (the Dynamic Stochastic General Equilihrium (DSGE) models).

\subsubsection{Stable and unstable adjustments}

When an economy is disturbed from (say its full employment) equilibrium, there is a further question: are the underlying economic forces such that it will (quickly) return? Standard economic analysis focuses on equilibrium. It is assumed that somehow all individuals can figure out precisely what reeds to be done to restore the economy to the presumed equilibrium path. Of course, if there were a central planner calling off prices, he could iterate until he found the equilibrium, at which point the economy could proceed. But there is no such central planner, price adjustments occur in real time, and are made sep. arately by millions of price setters in the economy, and there is little theory to suggest that the way they set prices will converge quickly to the equilibrium. Out of equilibrium trades have balance sheet effects, and themselves affect the future evolution of the economy.

A closer look at the behavior of market processes suggests that the dynamics are often disequilibrating, that is, the initial response to some disturbances is to move the economy further away from equilibrium. Thus, consider what happens when an adverse shock to aggregate demand leads to unemployment Higher unemployment puts downward pressure on real wages, shifts the distri bution of income toward profits, and, if the share of profits that are consumed is lower than that of wages, this lowers aggregate demand further. ${ }^{21}$ Accelerator effects (on investment) reinforce these consequences. Unemployment increases still further. Thus, the decentralized market response to the deficiency in aggregate demand is to increase it further.

Interestingly, making markets more flexible may exacerbate the disequiibrating dynamics. If wages fall faster, then the distribution of income changes more adversely against workers, and aggregate demand falls further. Thus "improvements" in markets, which have led to more labor market flexibility, may have exacerbated market instability.

Many of the other somcalled market reforms have both exposed countries to more shocks and weakened the automatic stabilizers - capital and financial market liberalization and tariffication have enhanced the potential for external shocks to disturb dornestic markets; and the move from defined benefit to defined contribution pension prograns, the greater reliance on capital adequacy standards, rigidly enforced, and on simplistic rules, like balanced budget frameworks for governments, have weakened automatic stabilizers and sometimes replaced them with automatic destabilizers.

Regimes for exchange rate adjustments reflect an ongoing debate on the relationship between market flexibility and dynamic stability. As we noted, the fixed exchange rate systems of the past were viewed as introducing a rigidity in adjustment, which led to crises; they made adjustment costly, so that adjustments occurred only when the official exchange rate differed markedly from that which would have prevailed in the absence of government intervention. The resulting adjustments, when they occurred, were large, precipitating a "crisis." The hope was that moving to flexible exchange rates would enable adjustments to occur smoothly, so there would be no crisis. What has happened in the forty years since the abandonment of the fixed exchange rate system (especially in the last thirty years) has shown that that hope was misplaced. There continue to be crises, marked by sudden changes in exchange rates and/ or changes in prices in financial markets with concomitant large changes in the level of economic activity.

In resporse to some of the earlier crises, advocates of flexible exchange mas blame covernments from interfering in markets, trying to maintain a quai-peg. It was government, again, rather than markets, that were the problem. But there were two problems with that conclusion. First, and most importantly, crises (or at least sudder and marked changes in exchange rates of the prices of assets) occurred in countries where governments did no intervene. Secondly, it was clear that markets before the crises had underestimated the risk of these crises, and the resulting mispricing (for example, of risk) had contributed to the magnitude of the crisis. The fact that, say, in the run up to the euro crisis, markets had lent so much money on stuch favorable terms to Spanish borrowers (including Spanish banks) simply because it was part of the euro and on the presumption that therefore the debts could and 
would be repaid contributed to the real estate bubble in that country. There was no way of absolving markets of their failed judgments in helping create many of the crises around the world. ${ }^{22}$

Let me relate the discussion of the past few paragraphs to the earlier discussion, which focused on a typology of equilibritum models. That discussion was couched in terms of the usual non-stochastic dynamics. I didn't discuss, say, within the context of a model with a tnique equilibrium whether the convergence to that equilibrium would be monotonic or fast. In some cases, it may not be. There can even be limit cycles, where the economy does not converge to a stationary state.

With stochastic processes, it should be clear that when there are multiple equilibria without stochastic elements, then the stochastic shocks could move the economy from an orbit of attraction for one equilibrium to that of another. Even small shocks could have large consequences, both in the short run and the long. ${ }^{23}$

Moreover, large disturbances in more complex dynamic processes may entail complex processes of restoration of the original equilibrium - or a move to a new equilibrium. Thus, consider the proposition made earlier that consistent with any level of leverage, there is a full employment equilibrium. Leverage only affects the distribution of income. But at a given set of wages and prices, high leverage does depress consumption, lowering aggregate demand including demand for housing. If that happens, the adverse real balance shee effects lower housing prices weaken consumption (and aggregate demand) further. Since the cost of housing includes the capital loss (gain), expectations of further losses (smaller gains) lowers demand further. That there may be a configuration of prices and wages at which full employment is attained even with the existing level of debt is irrelevant: the short run dynamics of the economy has the economy in a downward spiral. ${ }^{24}$

\subsubsection{An important exception}

As 1 have noted, standard competitive equilibrium theory says that corresponding to any initial set of endowments there exists a sets of wages and prices (extending infinitely far into the future) such that all markets clear, that is, the demand for labor equals the supply of labor every period. There is full employment. So far, our attention has been focused on adjustment - on the possibility that the decentralized dynamics of a market economy do not lead to that equilibrium, or at least do not do so quickly. But there is another possibilify. ${ }^{25}$ Today, markets for goods and labor at future dates (in a variety of states of nature) do not exist. Behavior today is affected by expectations of the prices (wages, interest rates) that will prevail in the future. Those expectations themselves may not be market clearing. That is $s_{t}$ even if there existed a future path of actual prices (including wages) at which markets would clear at all dates, there can also exist a path of expected prices (which may or may not be realized) at which markets don't clear. And the way that individuals form their beliefs may be such that the path of expectations which would have resulted in markets clearing (that is, full employment in every period) cannot be attained.

It should be obvious that it would not have been rational for individials to have assumed that the economy, in 2008 , would quickly be restored to full employment. So, in a sense, it should be obvious that strictures of rational expectations cannot rule out these non-market clearing equilibrium (see also Neary and Stiglitz, 1983).

Thus, if individuals, seeing a fall in prices, anticipate that there will be further declines, and on the basis of that decide to postpone buying durables (including housing), price declines will not result in the hoped for increase in consumption and aggregate demand. Again, the natural dynamics could lead the econony further away from the full employment equilibrium.

1.1.1.4 Asset prices, divergent expectations, and crises

The fact that there can be sudden changes in expectations (whether rational or not) about the future means that there can be sudden changes in asset values, and that itself can lead to (reinforcing) sudden changes in behavior. This is especially the case in the presence of financial constraints, where the envelope theorem no longer holds. That is, in the absence of such constraints, an individual optimizes, given his endowment, and a small change in endowment leads to a small change in behavior. But with binding financial constraints, small change in dsset values (say in the value that an individual can put up as collateral against a loan) leads to a first-order change in behavior.

In fact, history is replete with examples of credit and other bubbles that were almost surely irrational. Behravior was based on the belief that these bubbles would continue, in a way that was surely virtually impossible. So too, market participants did not fully understand the implications of certain financial products or tules of the game, ${ }^{26}$ and while "rationality" might not entail perfect understandings by all market participants, the disparity between the world as they saw it, and the world as they should have seen it, makes clear that if it incredulous to dignify such beliefs as "rational."

For instance, consider the variable rate mortgages that became fashionable in the run up to the subprime mortgage crisis. A stupposed financial expert, Alan Greenspan, seemingly advised borrowers on the advantages of these mortgages, noting that had they taken out these mortgages say a decade earlier, they wotld have fared far better than they would have with fixed rate mortgages. ${ }^{27}$ There were two things that were striking about this advice (cautioned as it was by the observation that what happened in the past provides no assurance for what will happen in the future). First, if markets were based on rational expectation (and, ironically, Greenspan was among those who believed markets functioned 
well), then there should be little difference between the expected cost of a variable and a fixed rate mortgage; the only difference was the pattern of risk, and that was much worse (for the typical homeowner) with a variable rate mortgage. Secondly, the main reason that variable rate mortgages had done better during the previous decade was that Greenspan had towered rates in an unprecedented manner, in a way that could not have been built into expectations and market prices at the time the mortgages would have been taken out. With interest rates at record lows, the likelihood of them falling further was small, and the risk that they might rise (as they did) considerable.

I dwell on this example not to berate the chairman of the Fed, but rather to emphasize that if seemingly sophisticated financial experts cotld get things so wrong, what should we expect from ordinary mortals? We should not be surprised if they have beliefs that are suddenly disproved by a turn of events, and that, when that happens, they suddenly change behavior. And sometimes that sudden change in behavior induces a crisis. That is the story of the euro crisis, which is the focus of the second part of this essay.

\subsubsection{Debt, debt restructuring, and equilibrium dynamics}

But before turning to the euro crisis, there is one general application of the principles laid out in the previous sections that needs to be discussed, related to the problem of debt overhang. As we noted, debt simply represents a claim on resources; it should affect the distribution of the "pie," not the size of the pie. Well-functioning markets should enable the economy to continue to operate at full employment.

It is worth asking, then, what the putative equilibrium might look like. lgnoring, for the moment, the relatively small changes in aggregate demand that might result from changes in labor supply as a result of changes in wages and prices, the question then is - how can aggregate demand be restored to the level of aggregate supply? One possible answer is that there be a redistribution from those with low marginal propensities to consume to those with a higher marginal propensity to consume. That minght be accomplished by a marked increase in wages, a movenent in wages the opposite of what normally happens in an economic downturn, and one that is hard to reconcile with an "equilibrium" theory in which real wages are equal to the matginal productivity of labor; for so long as output is approximately the same (as before the crisis), the marginal productivity of labor will be (approximnately) the same. (Of course, if the distribution of income is affected by the extent of successful rent seeking, then the distribution of income can be changed, but that will require political action.)

Another possible answer is an increase in wages and prices, for with debt contracts not being indexed, large increases in prices reduce the value of the debt owed by the (mostly poon) debtors to the (mostly rich) creditors. The redistribution (of wealth) should result in an increase in current consumption. It would amount to the deleveraging that is often cited as needed in the current economic downturn. But achieving this may not be easy. Standard equilibrium theory identifies the set of wages and prices such that all markets (include that for labon) clear; however, typically no reference is made to past prices. History matters only with respect to the stocks of inherited assets. But to go from the pre-crisis equilibrium, where demand was supported by a (possibly irrational) bubble, to the post-crisis equilibrium requires a large and dramatic change in price levels.

There are two problems: First, it is hard for this to be achieved in a setting of decentralized price and wage setting. Indeed, in that context, economic forces move the economy in the opposite direction: there is a tendency for prices and wages to fall, increasing the debt burden, and decreasing aggregate demand.

Secondly, government (and especially monetary authorities) won't allow it. If prices should somehow jump in the way that would be required, they would worry that inflationary expectations would be brought into play. Moreover, there is the question of whether prices could increase to the requisite level without accommodating monetary policy.

The issue of inflationary expectations is more complicated than is sometimes suggested. For expectations are always conditional - that is, they are dependent on circumstances. Crises happen only rarely. Exen if individuals believed, on the basis of this one experience in which a crisis government allowed a sudden increae in the level of prices, that in the future it might do so again, the implications would be limited. It would neither mean that there would be inflationary expectations going forward (they could and should rationally expect that this was a one-time adjustment in the price level, to obliterate the debt that was holding down the economy) or that there would be inflation in non-crises periods. And given the rarity of crises, it would not mean that individuals' willingness to hold money would be significantly affected. (There are a host of experiences in which such one-time adjustments have occurred without affecting future behavior, at least in out-of-crisis periods. It is not even necessarily rational for them to believe that in future crises, the economy would respond in a similar way. Not only is the economic structure likely to be markedly different - normally, long time spans separate crises - but the government is likely to have changed, and even thinking about how the government should respond to crises is likely to have changed.)

By the same token, the fact that the "once-and-for-all" increase in the price level will have largely obliterated the value of the debts implies that individtals wotld not be willing to lend. For all lenders recognize that there is a risk of loss, and a greater risk of loss with some loans than others (reflected in different risk premia). After crises in which significant capital losses have been incurred, individuals return to lending - and, indeed, even countries which 
have defaulted on their debts typically return to the capital market after a relatively short period of time.28

In a sense, after any crisis someone risks a major loss in the value of a key asset. The question is who, and how the loss occurs. In the current process, in which the economy remains in a severe downtum for a prolonged period, it is owners of human capital that experience large losses. In the East Asian crisis, in Korea, for instance, there were large numbers of bankruptcies. Equity value were wiped out, and creditors took considerable losses. The large change in expectations necessarily leads, as we noted, to large changes in capital values But the failure either to adjust prices or to restructure debts imposes aduitional deadweight losses resulting from the underutilization of resources, as a consequence of deficiencies in adequate demand.

There is an alternative way of restoring the economy to full employment, one that is not widely discussed in the context of the conventional competitive general equilibrium model, in which bankruptcy plays no role. At differen prices (and wages) some individuals are unable to meet their debt obligations, and there is, under bankruptcy law, a change in debt obligations and ownership claims. Different legal frameworks have different distributive consequences - and therefore different consequences for aggregate demand at a particular moment in time. Thus, if I can fully discharge my debt if my current income is less than my current debt obligations, there can be a large transfer of wealth from my creditors to myself, allowing me to increase my consumption today, and leading them by the same token to reduce their consumption. ${ }^{29} \mathrm{But}$ if my marginal propensity to consume is much larger than theirs, aggregate consumption will increase. Clearly, consumption today (and also aggregate demand) will be different within a different legal framework, for instance, one in which student debt can never be discharged,

\subsubsection{Further mitigation of the adverse effects of debt crises}

We argued earlier that the real costs of a crisis often occur after the event (after the breaking of the bubble, or after the adiustment of the exchange rate, for example), in the persistent underutilization of resources. Thus, policies directed at returning the economy to full employment are likely to greatly mitigate the cost of the crisis. The previous paragraph described how a well-designed bankfuptcy law, quickiy enforced, could help do so.

But crises eviscerate bank balance sheets, which impair lending, thereby weakening the economy. (This is true both when a credit bubble bursts, or when exchange rates fall, and debtors have foreign denominated liabilities.) As Greenwald and Stiglitz (2003) have emphasized, there is specialized information, for example, about particular borrowers, embedded in banks. When banks go bankrupt, there can be large costs associated with the resulting loss of institutional knowledge; but even short of barkruptcy, it banks balance sheets are weakened, lending will be constricted, in a way that cannot easily be compensated for, either by expanded lending by healthy banks or through capital markets (because of the important, pervasive information asymmetries).

What is required then is the recapitalization of the banking system. Unfortunately, in the midst of a crisis, banks may be neither willing nor able to do so. If they can get access to finance, especially equity, it may be at such disadvantageous terms that the owners of the banks are reluctant to take it. Access to liquidity - government lending - helps only a little; the problem is that with a shrunken balance sheet (equity), they are unwilling to undertake tisky lending. Preferred shares are little different.

Typically, governments have succeeded in fecapitalizing banks through a variety of opaque mechanisms. Regulations suppressing deposit rates allow them to earn a spread between the lending rate and the artificially low deposit rate. Government (reserve bank) lending at low interest rates (close to zero in the recent crisis), while allowing or encouraging banks to take that money and invest it in higher yielding (government) assets is nothing more than a gift: it takes no genius to borrow at $7 / 4$ percent, lend to the government at 3 to 7 percent, and make a tidy profit.

It is understandable that there are strong political objections to these nontransparent redistributions to the banks, especially in the current context, where they are widely believed to have played a central role in causing the crisis and in exploitation. "Forced" recapitalization - a form of partial nationalization, where the banks are forced to take government equity $\sim$ may be an effective way of inducing more lending, even if the banks' managers continue to act in the interest of the private shareholders. For the risks that the "private" owners face (including the risks that arise in the event of bankruptcy) has been reduced. ${ }^{31}$

For a sovereign facing a debt crisis, ore major problem is the deficiency of aggregate demand that arises from the transfer of funds to service the debt. While (again) there should be some configuration of wages and prices (and/or other policies) that would succeed in sustaining full employment, achieving that may not be easy. Debt restructuring (partially reneging on the debt) is an alternative, just as it is in the case of private debt. But, unfortunately, there is no sovereign debt bankruptcy "law," no sovereign debt restructuring mech anism. The result is that such restructuring, even when the discharge of the debt provides room for more expansionary policies to restore the economy to full employment, often appear highly risky.

There has heen an extensive debate about the costs of such restructuring. Traditional models (Eaton and Gersovitz, 1981; Eaton, Gersovitz, and Stiglitz 1986) have emphasized the cost of losing access to credit. But more recent literature has questioned both theoretically and empirically whether that actually occurs, and, if so, the costs. ${ }^{32}$ Rather, it appears that the costs are often 
associated with the failure to adequately insulate domestic institutions from the consequences of the debt default, that is, domestic banks that have large holdings of government debt may become bankrupt, or sufficiently weakened that they are forced to curtail lending. But much of these costs are avoidable, if the government anticipates them and takes countervailing actions, such as by recapitalizing the banks, as described above.

of course, creditors have every reason to scare debtor countries into believing that there will be strong adverse effects, effects which will be more severe the greater the magnitude of the debt restructuring. This is true even if prior to the crisis they had earned large excess returns, reflecting a risk that such a defatt might occur.

Argentina has shown that there can be "life after debt," life after a large economic crisis, associated with a significant financial and currency crisis and a large debt restructuring. The debt and high exchange rate had imposed a huge cost on the economy in the years before the crisis. The dramatic adjustment in prices (exchange rates) and debt restructuring enabled the econony to return to robust growth, with much lower unemployment than in the years preceding the crisis, with the government in a much stronger fiscal position, the current account restored to a sustainable position. No government - and especially a newly installed government - can fully plan for a crisis of the magnitude of that which occurred in Argentina. But what is clear is that they managed to "solve" in a reasonable way the host of distributional and other isstes that had to be addressed in the process of the devaluation and debt restructuring.

One might argue that the overall costs would have been reduced had Argentina restructured and devalued earlier. ${ }^{33}$ it is understandable why governments - fearful of the consequences, including the political consequences for their own fortunes - hesitate. A mote orderly restructuring process, through a sovereign debt restructuring mechanism, would reduce those fears, and hence the overall costs.

Those in the financial market, by contrast, often seem to want to increase those costs. They worry that if defatil (bankruptcy sovereign debt restruc. turing) is too easy, there will be an increase in defauts. That would necessitate an increase in interest rates. And that would reduce borrowing. But as Jeanne and Korinek (2012) have shown, there are macroeconomic externalities that arise from borrowing in foreign exchange. Markets by themselves are likely to lead to excessive borrowing. Surely the benefits to Argentine of its excessive borrowing in the 1990 s was overshadowed by the costs it bore subsequently. Similarly for Latin America in the 1970s. Arguably, then, the new equilibrium which would emerge - less borrowing, fewer debt crises, greater economic stability, would be preferable to the current system marked by repeated crises and a high level of instability.

\subsubsection{The fundamental flaws in the Euro Zone framework}

The euro was a political project, conceived to help bring the countries of Europe together. It was widely recognized at the time that Europe was not an optimal currency area ${ }^{34}$ Labor mobility was limited, the countries' ${ }^{\prime}$ economies experienced different shocks, and there were different long-term productivity trends. While it was a political project, the politics was not strong enough to create the economic institutions that might have given the euro a fair chance of success. The hope was that over time, this would happen. But, of course, when things were going well, there was little impettus to "complete" the project, and when a crisis finally occurred (with the global recession that began in the United States in 2008) it was hard to think through carefully what should be done to ensure the success of the euro.

I and others who stpported the concept of European integration hoped that when Greece went into crisis, in January, 2010, decisive measures would be taken that would denonstrate that the European leaders at least understood that further actions would be needed to enable the euro to survive. That did not happen, and quickly, a project designed to bring Europe togetter became a source of divisiveness. Germans talked about Europe not being a transfer union - a euphemistic and seemingly principled way of saying that they were uninterested in helping their partners, as they reminded everyone of how they had paid so much for the reunification of Germany. Not surprisingly, others talked about the high price they had paid in World War II. Selective memories played out, as Germans talked about the dangers of high inflation; but was it inflation or high unemployment that had brotght on the political events that followed?

Greece was castigated for its high debts and deficits, and it was natural to blame the crisis on excessive profligacy, but again there was selective memory: In the years before the crisis bit Spain and Ireland had low debt to GDP ratios and a fiscal surplus. No one could blame the crisis that these countries faced on fiscal profligacy. It was thus clear that Germany's prescription, that what was required were stronger and more effectively enforced fiscal constraints, would not prevent a recurrence of crisis, and there was good reason to believe that stronger constraints - austerity - would make the current crisis worse. Indeed, by so manifestly showing that Europe's leaders did not wnderstand the fundamentals underlying the crisis - or that if they did, by manifesting such enormous resistance to undertaking the necessary reforms in the European framework - they almost surely contributed to the markets' lack of confidence, helping to explain why each of the so-called rescue measures was viewed as only a temporary palliative.

In the remainder of this section, I describe several of the tunderlying structural properties of the Euro Zone that, if they do not make crises inevitable, 
certainly make them more likely to occur. (What is required is not so much the structural adjustment of the individual countries, but the structural adjustment of the euro framework.) Many of these were rules that reflected the neoclassical model, with the associated neolibexal policy prescriptions, which were fashionable (in some circles) at the time of the creation of the euro. Europe made two fundamental mistakes: first, it enshrined in its "consti tution" these fads and fashions, the concerns of the time, without providing enough flexibility in responding to changing circumstances and understandings. And secondly, even at the time, the limits of the neoclassical model had been widely exposed - the problems posed, for instance, by imperfect competition, information, and markets to which I alluded earlier. The neoclassical model failed to recognize the many market failures that require government intervention, or in which government intervention would improve the performance of the economy. Thus, most importantly from a macroeconomic perspective, there was the belief that so long as the government maintained a stable macro-economy - typically interpreted as maintaining price stability overall economic performance would be assured. By the same token, if the govermment kept budgets in line (kept deficits and debts within the limit set by Maastricht Convention) the economies would "converge," so that the single currency system would work. The founders of the Euro Zone seemed to think that these budgetary/macro-conditions were necessary and essentially. sufficient for the cotntries to converge, that is, to have sufficient "similarity" that a common currency would work. They were wrong. The founders of the Euro Zone were also focused on government failure, rather than market failure, and thus they circumscribed governments, setting the stage for the market failures that would bring on the euro crisis.

Much of the framewotk built into the Euro Zone would have enhanced efficiency, if Europe had gotten the details right and if the neoclassical model were correct. But the devil is in the detall, and some of the provisions, even within the neoliberal framework, led to inefficiency and instability.

Free mobility of factors without a common debt leads to the incficient and unstable allocation of factors. The principle of free mobility is to ensure that factors move to where (marginal) returns are highest, and if factor prices are equal to marginal productivity, that should happen. But what individuals cate about, for instance, is the after-tax returns to labor, and this depends not only on the marginal productivity of labor (in the neoclassical model) but also on taxes and the provision of public goods. Taxes, in turn, depend in part on the burden imposed by inherited debt. Ireland, Greece, and Spain face high levels of inherited debt. In these countries, the incentive for outmigration, and is especially so, because that debt did not increase to its current levels as a result of investments in education, technology, or infrastructure that is, through the acquisition of assets, but rather as a result of financial and macro economic mismanagement. This implies migration away from these highly indebted countries to those with less indebtedness, even when marginal productivities are the same; and the more individuals move out, the greater the "equilibritum" tax burden on the remainder, accelerating the movement of labor away from an efficient allocation..$^{35}$ (Of course, in the short run, migration may have positive benefits to the crisis country, both because it reduces the butden of unemployment insurance, and as the remittances back home provide enhanced domestic purchasing power. Whether in the short run these "benefits" to migration outweigh the adverse effects noted above is an empirical question. The migration also hides the severity of the underlying downturn, since it means that the unemployment rate is less, possibly far less, than it otherwise would be. ${ }^{36}$

Free mobility of capital and goods without tax harmonization can lead to an inefficient allocation of capital and/or reduce the potential for redistributive taxation, leading to high levels of after-tax and transfer inequality. Competition among jurisdictions can be healthy, but there can also be a race to the bottom. Capital goes to the jurisdiction which taxes it at the lowest rate, not where its marginal productivity is the highest. To compete, other iurisdictions must lower the taxes they impose on capital, and since capital is more unequally distributed than labor, this reduces the scope for redistributive taxation. (A similar argument goes for the allocation of skilled labor.) Inequality, it is increasingly recognized, is not just a moral issue: it also affects the performance of the economy in numerous ways (Stigitz, 2012).

Free migration might result in politically unacceptable patterns of location of economic activity. The general theory of migration/local public goods has shown that decentralized patterns of migration may well result in inefficient and socially undesirable patterns of location of economic activity and concentrations of population. There can be congestion and agglomeration externalities (both positive and negative) that arise from free migration. That is why many countries have an explicit policy for regional development, attempting to offset the inefficient and/or socially unacceptable patterns emerging from unfettered markets.

In the context of Europe, free migration (especially that arising from debt obligations inherited from the past) may result in a depopulation not only of certain regions within countries but also of certain countries. One of the important adjustment mechanisms in the United States (which shares a common currency) is migration; and if such migration leads to the depopulation of an entire state, there is limited concern. ${ }^{37}$ But Greece or Ireland are, and should be, concerned about the depopulation of their countries.

The single market principle for financial institutions and capital too can lead to o regulatory race to the bottom, with at least some of the costs of the failures borne by 
other iutisdictions. The failure of a financial institution imposes costs on others (evidenced so clearly in the crisis of 2008), and governments will not typically take into account these cross-border costs. That is why either there has to be regulation by the host country (Stiglitz et al. 2010), or there has to be strong regulation at the European level.

Worse still, confidence in any country's banking system rests partially in the confidence of the ability and willingness of the bank's government to bail it out (and/or to the existence of institutional frameworks that reduce the likelihood that a bailout will be necessary, that there are funds set aside should a bailout be necessary, and that there are procedures in place to ensure that depositors will be made whole). Typically, there is an implicit subsidy, from which banks in jurisdictions with governments with greater bailout capacity benefit. Thus, money flowed into the United States after the 2008 global crisis, which failures in the United States had brought about, simply because there was more confiderice that the United States had the willingness and ability to bail out its banks. Similarly, today in Europe: what Spaniard or Greek would rationally keep his money in a local bank, wherk there is (almost) equal convenience and greater safety in putting it in a German bark $?^{38}$ Only by paying much higher interest rates can banks in those countries compete, but such an action would put them at a competitive disadvantage; and the increase in interest rates that is required may be too great - the bank would quickly appeat to be non-viable. What happens typically is capital flight (or; in the current case, what has been described as a capital jog: the surprise is not that capital is leaving, but that it is not leaving faster). But that sets into motion a downward spiral: as capital leaves, the country's banks restrict lending, the economy weakens, the perceived ability of the country to bail out its banks weakens, and capital is further incentivized to leave.

There are two more fallacies that are related to the current (and inevitabie) failures of the Euro Zone. The first is the belief that there are natural forces for convergence in productivity, without government intervention. There can be increasing returns (reflected in clustering), the consequence of which is that countries with technological advantages maintain those advantages, unless there are comntervailing forces brought about by government (industrial) policies. But European competition laws prevented, or at least inhibited, such policies. ${ }^{39}$

The second is the belief that necessary, and almost sufficient, for good macrow economic performance is that the monetary authorities maintain low and stable inflation. This led to the mandate of the European Central Bank to focus on inflation, in contrast to that of the Federal Reserve, whose mandate includes growth, employment, and (now) financial stability. The contrasting mandates can lead to an especially counterproductive response to a crisis, especially one which is accompanied by cost-push inflation arising from high energy or food prices. While the Fed lowered interest rates in response to the crisis, the continuing inflationary concerns in Europe did not lead to matching reductions there. The consequence was an appreciating euro, with adverse effects on European output. Fad the ECB taken actions to weaken the euro, it would have stimuiated the economy, partially offsetting the effects of austerity. As it was, it allowed the US to engage in competitive devaluation against it.

It also meant that the ECB and central banks within each of the member countries) studiously avoided doing anything about the real estate bubbles that were mounting in several of the countries. This was in spite of the fact that the East Asian crisis had shown that private sector misconduct - even when there is misconduct in government - could lead to an economic crisis. Europe similarly paid no atterition to mounting current accourt balances in several of the countries.

Ex post, many policymakers admit that it was a mistake to ignore these current account imbalances or financial market excesses. But the underlying ideology then (and still) provides no framework for identifying good "imbalances," when capital is flowing into the cotntry becatse markets have rationally identified good investment opportunities, and those that are attributable to market excesses.

\subsubsection{The immediate problem}

The most inmediate problem facing the Euro Zone is that creating a single currency took away two of the critical adjustment mechanisms (interest rates and exchange rates) and did not put anything in their place. The United States has an economic framework that deals with most of the problems described earlier two-thirds of all government expenditures occur at the national level, and the states are restricted (by their own constitutions) from incurting debt, other than for capital projects. to $^{\circ}$ Most banks rely on federal deposit insurance. States are not restricted from engaging in "industrial policies," and poorer states have actively recruited firms to locate in their jurisdictions. ${ }^{4 !}$

Some hoped that internal devaluation wotld serve as an effective substitute, that is, there would be a fall in dorrestic wages and prices. But there are three fundamental problems with this solution: (a) it is hard to coordinate such decreases, and, in the absence of such coordination, there can be large and costly changes in relative prices; (b) because debt is denominated in euros, and is not contingent on domestic wages and prices, debt burdens increase - with adverse consequences for bankruptcy and disruption of the donestic financial system (c) the decrease in collateral values and incomes (especially relative to debts) would have tightened financial constraints, with first-order adverse effects on the economy. Most importantly, if internal devaluation were an effective substitute for nominal devaluations, then the gold standard would not have been an impediment to adjusting to the disturbances sturrounding the Great Depression. The fact that those countries that abandoned the gold standard earlier did bette is at least partially attributable to the resulting competitive devaluation. In the 
case of Argentina, before its 2001 crisis prices did fall, but not enough - again, an internal devaluation is not substitute for exchange rate adjustment

Europe has responded to the crisis by refusing to recognize that there were any fundamental structural problems in the EU arrangements. Like the IMF and the US Treasury in so many other crises (including the $2008 \mathrm{crisis}$ ), it initially saw the prohlem as a liquidity crisis, a temporary loss of confidence, If the IME, ECB and the Commission showed that they stood behind each of the countries, confidence would be restored, and the crisis resolved. All that was required was a temporary injection of funds (a loan to the bank or the country). But, of course, such loans don't improve the balance sheet of the country (or the bank), and if the problems are more fundamental, then they can have adverse effects on other claimants, especially if the bailouts are senior to other creditors and even more so if a high interest rate is charged. That's why the East Asian ballouts and the Argentinean bailotts had little discernible effect. It is not surprising that neither did the European bailouts; it is only sur prising that Europes leaders took so long to recognize this.

Later, the ECB lent money to the banks, to lend to the governments, to help support bond prices (lower sovereign yields), in the long-term refinancing operation (LTRO) program. Because the money lent to the banks was lent at close to zero interest tate, and the banks could on lend the money at much higher interest rates, this program was in effect a massive gift to European banks. The fact that European officials looked at the take-up of the program as a measure of "success" (as well as the temporary reduction in sovereigni risk premiums) was perhaps symptomatic of a lack of understanding of the underlying problems. To be sure, there were real effects from the hidden recapitalization of the banks. But the effects on sovereign risk premiums were temporary: onity coercion would induce them to permanently put a disproportionately large fraction of their balance sheet in these highly risky assets.

Indeed, there was something especially peculiar about Europe's attempt at a bootstrap operation, whereby lending to the government would heip bail out the banks, and lending to the banks would heip bail out the governments.

But at least this bootstrap attempt did not have the adverse effects of austerity: predictably, austerity lowered growth, and as austerity spread across Europe, it helped bring on a Europe-wide recession, weakening the banks at the same time that it had disappointing fiscal benefits. As growth slowed and the ranks of the unemployed swelled, revenues declined from what they otherwise would have been) and expenditures (for example, on unemployment payments) increased.

European officials who prescribed austerity suggested, when these programs were first adopted ${ }^{42}$ that by now those who adopted their programs would be on the way to restored prosperity. ${ }^{43}$ They have beerl wrong, and on repeated occasions. They have repeatedly underestimated the magnitude of the downtum that their policies would bring about, and, as a result, they have consistently underestimated the fiscal benefit that would be derived: deeper downturn inevitably result in lower revenues and more expenditures for tnemployment and social programs. Though they then try to shift the blame back on to the crisis countries for missing the fiscal targets, the fact is that it is theit misdiagnosis of the problem and the resulting wrong prescription that shotld be held accountable. Spain and Greece are in depression - there is no other way to describe the situation - and that depression is largely a result of misguided policies foisted on these countries (though their own leaders are to blame for having acquiesced, but their acquiescence was understandable; they saw the proposed solution as better than any alternative avallable to them).

Today, the problem in Europe is an inadequate level of overall demand, and austerity exacerbates this problem. As the downturn continues, banks are less willing to lend, housing prices decline, and households become poorer and poorer, and more uncertain of the future, depressing consumption further.

No large economy - and Europe is a large economy - has ever emerged from a crisis at the same time that it has imposed austerity. Austerity always, inevitably, and predictably makes matters worse. The only examples where fiscal stringency has been associated with recovery are in countries where reductions in government spending ate offset by increases in exports. These are generally small countries, typically with flexible exchange tates, and where trading partners are growing robustly. But that is hardly the situation confronting Europe's crisis countries today: their major trading partners are in recession and each has no control over its exchange rate.4

European leaders have recognized that its problems will not be solved withou a retum to growth. But they have failed to explain how growth can be achieved with austerity. So too they assert that what is needed is a restoration of confidence. Austerity will not bring about either growth or confidence. The failed policies on the part of Europe as it has tried, repeatedly, patchwork solutions, misdiagnosing Eutrope's problerns, have undermined confidence. Because austerity has destroyed growth, it has also destroyed confidence, and will continue to do so, no matter how many speeches are given about the importance of confidence and growth.

The austerity measures have been particularty ineffective, because the market understood that they would bring with them recessions, political turmoll, and disappointing improvements in the fiscal position, as a result of a decline in tax revenues. Rating agencies downgraded countries undertaking austerity measures, and rightly so. Spain was downgraded as the first austerity measures were passed: the rating agency believed that Spain would do what it promised, and it knew that that meant low growth and a worsening of its economic problems. 
By the same token, while structutal reforms will be important for future growth and standards of living of many of the European countries, including those currently afflicted with crisis, structural reforms take time. They affect long-term standards of living, but structural rigidities did not precipitate the crisis. It was a financial and real estate crisis that did that. ${ }^{45}$ Most of the structural reforms are supply-side measures ${ }_{F}$ but, as I noted, the problem today is an inadequacy of demand; worse, many of the structural reforms will exacerbate that problem, especially those which lead to lower wages and have adverse distributional effects.

\subsubsection{Responding to the crisis}

This analysis of the fundarlental flaws underlying the Euro Zone suggests set of policies which might help resolve the crisis. I say might: these reforms are necessary to make the euro work, but they are not necessarily sufficient The divergence between an optinal currency area and the Euro Zone - the divergences, fot instance, in economic structures which can give rise to desired changes in exchange rates, eithet in the short run (in response to shocks) or in the long run (in response to systemic differences in productivity and infiation trends) - may be too large to make a system of a single currency work.

\subsubsection{Mutualization of debt}

The first necessary reform is a common fiscal framework - more than and fundamentally different from an austerity pact, or a strengthened version of the Stability and Growth pact. As I noted, it was not overspending by govermmen that brought on Spain or Ireland's problems.

One of the fundamental problems confronting the Euro Zone is that current arrangements effectively meant that countries were borrowing in a currency over which they had no control - much like developing and emerging markets who borrowed in dollars or euros. The fact that it was their own currency was of some, albeit limited, help. There is no risk that the US will ever default on its debt, owed in dollars, simply because it controls the printing presses (a fact that at least one of the rating agencies seems unaware of). The value of those dollars might diminish were it to resort to such measures, but (politics aside) there is unlikely to be any event of sufficient moment to change expectations of inflation so dramatically as to bring on a crisis.

What is required then is "mutualization" of debt - European-wide debt, owed in euros. This would make Europe's debt similar to America's debt, and with Europe's overall debt to GDP lower than that of the US, presumably interest rates would be compatable. Such mutualization would lower interest rates, allowing more spending to stimulate the economy and restore growth.

The mutualizaton of debt could be accomplished through a number of institutional mechanisms (Eurobonds, $\mathrm{ECB}$ borrowing and on-lending to nations).
How to design such a system (in a way that did not lead to excessive borrowing) would take me beyond this paper. For now, I simply note: The position of some in Europe against such mutualization - that Europe is not a transfer union - is wrong on two counts. (a) It exaggerates the risk of default, at least the risks of default if debt is mutualized. And (b), at low interest rates, most of the crisis countries should have no trouble servicing their debts. ${ }^{46}$

Of course, in the absence of debt mutualization, there is a serious risk of partial default (which has already happened in the case of Greece). The irony is that existing arrangements may actually lead to larger losses on the part of creditor countries that a system of well-designed nutualization.

Any system of successful economic integration must involve some assistance from the stronger countries to the weaker. (The desirability of such transfets, even in the absence of economic integration, was evidenced by the Marshall Plan after World War II. Eutope itself has provided substantial funds to new entrants, to enable their economies to converge.)

\subsubsection{A common financial system}

The second necessary reform is the estabishnment of a common banking systen with deposits insured by a Europe-wide deposit insurance fund, and with common regulations and a common approach to resolution of insolvent banks. I have already explained why a common deposit insurance fund is required: without such an institution, funds will flow from the banking system of "weak" countries to the banks in strong countries, further weakening those that are already experiencing difficulties. But without a conmon regulatory system, a system with a common deposit insurance scheme could be open to abuse.

However, a common regulatory system should have scope for taking different macroprudential stances in different countries, or even regions within a country. We described earlier how having a single central bank took away an important instrument of adjustment - the interest rate. But there are a host of other regulatory provisions (such as capital adequacy requirements) which can be adjusted depending on the nuacroeconomic circunistances ${ }^{47}$ Lending standards for mortgages should, for instance, be tightened at a place or time where there appears to be a risk of a bubble forming. ${ }^{4 *}$

If the euro is to survive, further reforms that are desirable - and perhaps even necessary - entail a move toward tax harmonization, restricting the race to the bottom in capital taxation, and distortions caused by tax competition among countries. Industrial policies that would allow those behind to catch up are necessary to prevent further divergences within the countries of Europe.

1.1.2.5 Towards debt restructuring

For most Euro Zone economies, these reforms would suffice - for now. But there may be some countries (like Greece) where the cumulative inpact of past 
mistakes (both their own past budgetary mistakes and those that were foisted upon them in the early responses to the crisis) are such that more is needed. They will have to restructure their debts.

Debt restructuring (as I argued in the first section of this essay) is an essential part of capitalism. Every country has a bankruptcy law that facilitates the restructuring of debts in an orderly way. Though after the Argentine crisis, there were calls for the creation of sovereign debt restructuring mechanisms, one of President Bush's many sins was to veto that initiative. In the stbsequent years, when there were no sovereign debt crises, there was little concern about the issue. Elsewhere, I have described what such a mechanism might look like (Stiglitz, 2010b. see also Stiglitz and Zandi, 2012). But in the absence of such a mechanism, countries have to act on their own - as Argentina showed is possible.

But if some country needs debt restructuring to enhance growth, this should be done quickly and deeply. And one should not feel too sorry for the creditors: Lenders have been receiving high interest rates reflecting such risks. ${ }^{49}$ By the same token, as we noted earlier, the costs to the econonies doing the restructuring may be less than is widely suspected. Both theory and evidence suggests that countries that do stuch restructuring can regain access to global financial markets; but even if, going forward, countries have to rely on their own savings, the adverse consequences may be far less than the benefits they receive from the debt restructuring, ${ }^{50}$

Argentina has also shown that there is life after debt and the reform of monetary arrangements. Indeed, there are good reasons to believe that a deep debt restructuring will have positive benefits - providing more fiscal space for expansionary policies, so long as the government does not have a primary deficit. It is important that the debt write-down be deep - otherwise the lingering uncertainty about the possibility of another debt restructuring will cast a pale over the recovery. And because of the uncertainty about future growth, and therefore of debt sustainability, GDP-indexed bonds may represent an effective form of risk-sharing (which can be thought of, at the sovereign level, as the equivalent of the conversion of debt into equity, at the corporate level) (see Miller and Zhang (2014), Griffith-Jones (2014)).

1.1.2.6 The end of the euro?

The analysis of this paper has staggested that prospects that the 17-nation Euro Zone will survive, in its current form, without significant reforms, are bleak. Its end, as its creation, is as much a matter of politics as of economics. European leaders continually affirm their commitment to do what is required to sustain it; but, at the same time, key Etropean leaders have shown that they do not seem to understand what is required to sustain it, and have ruled out many of the necessary measures. They have continually repeated a mantra - that one has to restore confidence and grow the economy - as they have simultaneously undertaken measures that have undermined long term confidence and have put the economy into recession.

Ever when most Ettropean leaders seem to gradually grasp what is required there are two fundamental problems: (i) can they achieve the unanimity required, given differences in the perspectives and interests and politics in the different countries; and (ii) can they achieve the requisite agreements fas enough? The incongruity between the pace of markets and that of the politics could present a problem for the survival of the euro. Indeed, the slow pace at which the fundamental problerns ate being addressed is alteady causing problems: the financial sector of the crisis countries continues to be weakened, both as atsterity exerts its toll on the economy and as capital leaves the country. This means that the magnitude of the assistance that eventually may be required is likely to be far greater than th would have been had the reforms been undertakerl earlier. ${ }^{\text {st }}$

Many European leaders have recognized that eventually a single banking framework, with common regulations, deposit insurance, and resolution, is necessary. But some European leaters argue that such a drámatic reform mus be done carefully, in a step-by-step process. First, there must be common regulations, and only when the regulatory system has been "proven" can Europe go on to the next stage(s). Were there not an ongoing crisis, such an argument would have some merit. But those with capital in, say, the Spanish banks will not wait: the benefits of waiting are nil, the risks are sttbstantial. And so, while European leaders dither, the banking system may be effectively destroyed.

ECB lending (in the unlimited amounts promised, provided that the country requests it and subjects itself to conditionality) may delay the day of reckoning. But one should be clear that the issue facing, say, the Spanish banks is not just one of liquidity. If the funds are accompanied by the kinds of austerity conditionality that has marked earlier programs, unaccompanied by any program that would lead to growth, then the banks will continue to weaken; and even the anticipation that this might be so will contribute to funds leaving the bank. What is necessary for a teturn of "confidence" in the banking system is: (a) a belief that further losses will be limited; and (b) the government has the resources and willingness to rescue the bank, should it run into problems. But under current policies, not only are the banks losses likely to continue to mount, the government's ability to rescue the banks will continue to deteriorate.

Alternatively, those with funds in Spanish banks might be willing to keep their funds there, were they confident that Europe will step into the breach. But Europe's equivocation has not helped, as Northern Europe has attempted to limit its exposure, responding to domestic political pressures. After recognizing that there needs to be a common financial framework, again there appears 
to be some backtracking: it has been suggested that perhaps only the large banks should be included. (While the failure of a single small bank would not itself cause large systemic effects throughout Europe, the failure of a number of small banks could; and what is at stake is not just "systemic risk" of Europe's financial system, but the capacity of the Spanish banking system to provide credit, especially to SME's, and this credit may be even more dependent on the strength of the smaller banks than on that of the larget banks.)

There is likely to be turmoll in the process of the restructuring of the Eno Zone, and the resulting downturn could be significant. But under the current regime, the prospects for crisis countries are truly bleak: For some, depression as far as the eye can see. Europe has offered no alternative vision.

The current regime is also undermining the legitimacy of democratic economic institutions. The European project was a top down initiative. There was a very short period of prosperity ${ }^{52}$ - based in some countries on access to credit at irrationally low interest rates. The promises of sustained prosperity were not fulfilled. Not only did sustained macroeconomic growth not materialize, but inequality increased $\mathbb{f}_{r}$ and governments have been restrained in their ability to redress growing inequities. Evidently, the elites created a system that seens to have done well for those at the top.

In many quarters, thete is concern about the ceding of effective economic power - originally to Brussels' bureaucrats, but increasingly to German politicians - undermining national democracies.

There are a variety of ways in which the current form of the Euro Zone might end. There was, of course, in its creation the assumption that it would never end (though monetary arrangements have had to be changed frequentiy), and so there was no provision for contingencies similas to that which the Euro Zone is now facing. It might be ended by the ECB refusing to discount the bills of the banks of a member country - in elfect, ceasing to act as a central bank for that country, and forcing the country's old central bank to resume that role. It might end in a popular uprising against the continted depression forced on the crisis countries by Europe's leaders.

While, however, the break-up of the euro if it occurs is likely to be costly, there are some ways of reducing those costs. There is growing agreenient among econonists that the least costly form of break-up would entail Germany leaving the euro. The "new euro" (so defined) would almost surely depreciate relative to the German mark, correcting current account imbalances within Europe, strengthening growth in crisis countries, and enabling those countries to more easily meet their debt obligations.

At the same time, the stronger mark wothld enable Germany to meet its debt obligations easily. Some creditors might feel that they were cheated, being paid back in the depreciated (new) euro; but credit contracts are typically unindexed, and there are a host of contingencies which affect the real value of what is repaid. Creditors receive a risk premium for bearing those risks. Whatever happens has distributive consequences; other ways of having the Euto Zone dissolved entail adverse effects on borrowets.

\subsubsection{Concluding comments}

Most crises are manmade. They are not caused by famines or other natura disasters. They are often the result of unstable market processes - rather than a sudden change in government policies. On the other hand, government poiicies can affect both the likelihood of the occurrence of crises and also their consequences. Government policies can affect countries' exposure to risk, the structural stability of the system and impede or facilitate adjustments. The elimination of automatic stabilizers, and their replacement in some cases by automatic destabilizers, has introduced new instabilities into the economic system. Deregulation and financial and capital market liberalization has system. Deregulation and financial and capital market liberalization has up new channels by which the instabilities in one country can affect others (Stiglitz et al. 2006).

We have seen how institutional changes surrounding the Euro zone intended to create a more stable and prosperous economy - played out in ways that were, at the time of the founding of the etro, largely unanticipated, but which - at least in hindsight - were totally understandable given the structura flaws in the Euro Zone institutional arrangement. We have seen too how the policy responses to the crisis, as it unfolded, have, in many cases, only made matters worse.

There are alternative policies which would enthance stability, and, once a crisis has occurred, would be more likely to restore the economy to prosperity. But to adopt these policies one has to break out of the straitjacket of market fundamentalism/neoliberalism and much of conventional economics.

There was no sudden change in the underlying state variables describing the Etropean economy: no war that wiped out latge fractions of its physical and human capital stock, nor even an innovation or an economic transformation that would have led to rapid obsolescence. There have been sudden changes in expectations, and in our understandings: we know (or at least we should now know) that markets are not necessarily quickly self-correcting, that underregulated markets can give rise to bubbles and credit excesses, the fact that Greece or Spain have the same currency as Germany does not mean that Greek or Spanish debt is as safe as that of Germany, and it may not even fully eliminate exchange rate risk and, in ways that we have explained, may actually increase default risk.

Crises ate complex events, and it is inevitably overly simplistic to try and find a single-causal explanation. However, it should be clear that the euro crisis, 
like so many other crises, is attributable more to market excesses than to government profligacy. If government is to be blamed, it is for a failure to tame the (repeated) market excesses. (And even when there is government profligacy, the market is almost always a co-conspirator - lending excessively on easy terms, in its irfational optimism about the prospects of repayment.) Prevention entails understanding how to curb the excesses, and how to design institutional arrangements that limit the opportunity for such excesses. Resolution entails understanding how to ensure that, after a crisis, resources are put back to use as quickly as possible.

With or without such excesses, economies are exposed to shocks: different institutional arrangements increase the expostre to such shocks, amplify the effects, make the effects more persistent, and impede adjustment, thereby also increasing the risk of a crisis. Market forces by themselves may not only lead to endogenous disturbances (like bubbles), but may respond to shocks in a destabilizing way. Government intervention (for example, through debt restructuring, counter-cyclical macro policies, and well-designed bank recapitalizations) can reduce the enormous costs that have traditionally been associated with crises.

Crises are perhaps an inherent feature of capitalism. But they do not have to be as frequent, as deep, and as costly as they have been.

The standard macroeconomic models ignored history - capitalism had always been marked by large fluctuations, with great suffering. The models ignored key market failures that help explain persistent inefficiencies and instabilities. In doing so, they may have violated the central principle of Hippocrates: do no harm. For the policies and institutional arrangements based on these sinplistic models and theories created the preconditions for these crises and have contributed to the slow recovery from this Great Recession - a downturn which, while not as deep as the Great Depression, may begin to rival it in duration.

\section{Notes}

1 Paper presented to an International Economic Association Roundtable on "Debt Crises - How to prevent them, how manage them, how to ensure there is life after debt" held in Buenos Aires, August 13-14, 2012, and co-sponsored by University of Buenos Aires (UBA). I am indebted to the participants in the conference, and especially to my discussant, Martin Guzman to Daniel Heymann; and to Sandesh Dhungan for helpful comments, Many of the ideas discussed in this paper are the result of joint work undertaken with nny long term co-author Bruce Greenwald. I would also like to acknowtedge the research assistance of Ritam Chaudty and Eamon Kitcher-Allen. In the yeats intervening between the presentation of the paper and its publication, the enrocrisis, the subject of the second part of the essay, has evolved. For the most part. have left the discussion as it was, to convey the sense of the debate at that time. Most of what I work then remains relevent as this paper yoes to press.

2 Reinhart and Rogoff (2009)
3 Thereis, of course, by now ample evidence against the rational expectations hypothesis. See Akerlof (2002); Fuster, Laibson, and Mendel (2010); and Stiglitz (2011)

There is a slight caveat to these claims: a dramatic change in expectations (for instance, the realization that the was a cal estate bubble that just burst) changes the composition or denand, and the capital stock that was appropiate for the previous output mix may be less so for the new demand structure. in addition, there are measurement problems. measured output before the chiss was intated by the bubble real estate prices and by the seening assoc (2010). real estate sectors. See, for example, Stiglitz et al. (2010).

Moreover, the real puzzle is the slow recovery of employment: even if the capital stock were partially "destroyed," standard theory says that labor should be fully utilized. Much of the loss of output - the difference between actual output an potential output - atises from the persistence of high levels of unemployment.

5 See Fisher (1933)

That is, it takes time to rebuild balance sheets, and because of important information imperfections and asymmetries, there is, in effect, equity ationing (Greenwald, Wetss, and Stiglitz, 1984), so that firms (including banks) cannot instantaneously taise additional equity on the capital market to replace capital that has been lost as a result of an adverse shock. For an overview, see Greenwald and Stiglitz (2003). For a more tecent discussion of balance sheet recessions, see Richard Koo (2008 and 2010)

7 Roubini (2008) and Wolf (2008)

8 Though some economists have seen a connection between the two: the recycling of Chinese surpluses, some argued, helped fuel the bubble. But as Stiglitz (2010) argues, there was no necessity either that these surpluses lead to low US interest rates (the fed still had a role in setting interest tates) or that the ready suppiy of finance be allocated so poorly (in part a result of inadequate regutation).

9 In a more probabilistic context, it may be rational for countries to incur sufficiently high debt such that, with a non-zero probability, there are events that result in a credit constraint being binding, that is, countries will not be able to botrow further, or may not even be able to roll over their debt (Eaton and Gersovitz, 1982, and Eaton, Gersovitz, and Stiglitz, 1986). But the frequency of debt crises and the costs that they impose suggest that this "rational theory of excess indebtedness" cannot explain what is going on. An alternative explanation, not pursued in this paper, focuses on political economy considerations: the benefits of higher levels of indebtedness accrue to politicians at one time, the costs (for example, associated with the subsequent crisis) occur at a later date, and will therefore likely be borne by other politicians. In effect, the political process leads to discounting the future costs of the crisis at a high rate. This theory stggests that there are severe limits to democratic accountability, for example, that voters too are myopic or that the political process gives weight to those that are myopic.

10 Thus, as Delli Gatti et al. (2012a and $2012 \mathrm{~b})$ emphasize, the association noted by Reinhart and Rogoff, between long casting crises and firlancial crises tells us little Reinhart and Rogoft, between long casting crises and financial crises tells us little much less than they sugsest. The collapse or America's bankingsynem in the Great sequentce more than cause.

11 As of April 2013, real private nonresidential fixed investment in the United States (n) was still 8.4 percent below the pre-crisis high. Source: St. Louis Fed.

12 See Delli Gatti et al. (2012a and 2012b). 
13 Weak balance sheets on the part of some local banks and low real estate ptices may, however, continue to impair lending to small and medium sized enterprises. Excessive bousehold leverage may lead to lower levels of consumption, but it is not likely for plausible, at least with rational markets) that savings tates will fall much below their current level. The low savings rates observed prior to the crisis entailed the bottom 80 percent of Americans spending 110 percent of their incomes, on average.

14 Such multiple equilibria arise often in game theoretic models: if everyone believes that there will not be a run on the bank, there won't be; but if they do, there will be See Diamond and Dybvig (1983). Early examples arose in standard growth theory where capitalists had a relative preference to the capital intensive good. They arise too naturally in simple overlapping generations modets: if individuals believe the interest rate next period will be low, they may save a great deal to ensure that they have an adequate amount for retirement; and tf they do that, there will be a low interest tate the following period. But if they think the interest rate is going to be high, they will saye Iittle: and the interest rate will be high. See Stiglitz (2008). Se also the extensive literature on sunspot equilibria.

15 Though as we have alregty noted (and we will comment on further below) in any model providing a good desctiption of the actual behavior of the economy the model prove have alrow the assumption of rath a

the paradigm that has dominated macroeconomics for the past

16 See, for example, Guesnerie (2001) and Cass and $\$$ hell (1983). Indeed, shocks to trend varkables can lead to defauts in models with zation expectations. Even small shocks to trends can generate large changes in the present

It is ato tue the some

18 It is also thue that some or the "bad behavior was rationally exploiting institutional haws (for exante, "loo big to fall banks have an incentive to engage in excessive nisk taking), and some was a result of inherent market flaws arising out

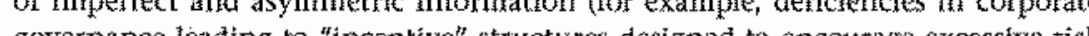
governance leading to "heentive" structures designed to encourage excessive risk taking.) Because most crises lavolve a combination of irrational expectations and rational explotation of institutional flaws, it is not possible (or even meaningful) to parse out the relative contribution of each. In principle, we could have a crisis fed solely, say, by rational expectations exploiting institutional deficiencies.

19 Irrationalles were evidenced not only in the size of the mortgages, but also in their form, in the rating agencies' ignoring the risk of correlated defaults and that the new forms of mortgages might have significantly higher default rates than traditional mortgages, in investors ignoring the perverse incentives of those originatin mortgages, those packaging them, and the rating agencies, etc. See Stiglitz (2010), 20 If anything, the fact that the government was willing to be so transparent should have been reassuring to the market.

21 The standard objection to the investment accelerator is that if tational individual had anticipated the decline in output, they would not have made the investments in earlier periods. The investment accelerator, in this view, depends on irrationa expectations. But the discussion above should have made it clear that if there is uncertainty in the growth path of the economy (either because of exogenous shock or endogenous) then it is possible that firms could have rationalyy over-invested, tha is, there were other possible trajectories (conceivable, even plausible at the time at which the investments were made, which would have justified these investments).

22 In Globalization and lts Discontents (2002), I describe similar irrationalities at play in the East Asian crisis.
23 Thus, as noted eatliet in footnote 7 , a shock could move the econonny from a situm ation whete a credit constraint was not binding to one where it was, from a situation whete it could roll over its debt (and therefore did not tace a credit crisis), to one where it cannot roll over its debt.

24 That dynamics of adjustment could be disequilibrating has long been recognized. See, or example, Neary and Stiglitz (1982). Standard theory assumes that somehow prices adjust instantaneously, and the econony smoothiy moves to the long fun rational expectations equilibrium, even if previous expectations, which proved so wrong, were believed to be rationals.

25 Beyond that which arises from other market imperfections, sttch as those associated with imperfect and asymmettic information, which can give rise to non-market clearing equilibrium.

26 That is certainly the case for many of the mortgage products and structured financial (2010).

27 See Alan Greenspan, "Understanding Household Debt Oblizations" the Credit Union National Association 2004 Governmental Affars Conference, Washington, DC February 23,2004 . Avatlabie at http:/www federalreserve gov/ Wash See, for example, Borenstein and Panizza (2008).

29 The two may not be fully offsetting; without the bankruptcy, the creditor might in the end have bet paid at most a faction of what was ow the end have been paid at nost a fation of whan was ow. Hasto

In the mist of a ris, the ma

0 In the midst of a erisis, here may be a need for an expedited debt restructuring, on a scale beyond that envisaged in normal bankruptcy law, though a "super chapter 11." see Miller and stghte (2010) and sightz (2000).

31 There are other mechanisms, such as partial insurance of new lending, or even better, the sale of macro-indexed Arrow-Debreu securities, where the bank is indemnified if the overall economy's economic performance is weak, resulting in a defaut rate that is higher than it otherwise would have been.

32 See, for example, Stiglitz (2010b) and the other papers in this volume

Orzag and Stiglitz (2002) discuss the optimal time to call the fire depar is, the optimal time to ask for assistance (a bailout) or to restructure.

34 See Mundell (196).

Interestiagly, this problem has long been recognized in the theory of fiscal federalism/local public goods. See, for example, Stiglitz (1977, 1983a, 1983b).

36 By the same token, if some of the butden of taxation is imposed on capital, it will induce capital to move out of the country.

37 Some see an advantage: buying influence over that country's senators because less expensive.

38 The exit from Spanish banks while significant - and leading to a credit crunch - has been slower than some had anticipated. This in turn is a consequence of institutional and market imperfections (tor example, rules about knowing your customer, designed to limit money laundering), which interestingly the neo-classical model underlying much of futope's policy agenda tgnoted, There is far less of a single market than it is widely thought.

39 Even the World Bank has changed its views on indtstrial policies; yet views about industrial poltcies are to a large extent enshrined in the Earo Zone's basic economic framewotk. See Lin (2012), Stiglitz and Lin (2013), and Stiglitz, Lin, and Patel (2013). 
40 These constitutional requtrements have, in recent years, been subverted by the crethion of unfunded pension liabilities, which may create within the states some of the same adverse dynamics described earlier for Europe.

41 Though this has created, to some extent, the tace to the bottom, the adverse dynamic that we described as characterizing Earope.

42 For example, British Conservative Prime Minister David Cameron in his Aptil 2009 speechl "The Age of Austerity" expounded on austerity not iust as a shorterm state crategy but as a philosophical shift that when

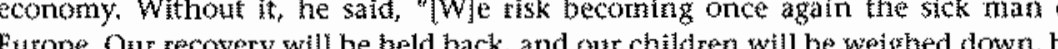
turope. Our ef a millstone of debt." The actual results of austerity in Britain have not lived up to
his promises, to say the least. his promises, to say the least.

sion of the preface to Stiglitz (2012).

44. Alesina and his co-authors have tried to propagate the idea that there can be expansionary contractions. But there is a growing consensus that their analyses are badly (2010), and that that is not the case See, for (2010), and jayadev and Konczal (2010).

45 As is the case in the United States, there may be deeper problems: structural transformation that is required by the decline in manufacturing employment and globalization.

46 The exception is Greece, for which there has already been debt restructuring.

47 One of the lessons of the crisis was that monetary atthorities relied excessively on interest rates.

Evidenced, for instance, by a rapid increase in housing prices relative to income, or by an abnormally rapid expansion of credit.

49 Or they should have done so, had they done their tute diligence.

50 As the paper by Sanderlis (2013) points out, the costs may be less related to those imposed externally, and more related to failufes of the government to deal effectively with the internal disturbances associated with debt restructuring, e.g. to th financial system (banking, insurance, and pensions).

51 The slow pace of teforms has led to other problems: Ireland, one of the first countries to receive assistance, is concerned that later countries will get a better "deal."

2 Monetary arfangements often have a short life span - witness the ERM. Even the Bretton Woods system (fixed exchange rates) lasted less than three decades.

\section{References}

Aguiar, M. and Gopinath, G. (2006) "Defaultable Debt, Interest Rates, and the Cutrent Account," Youmal of Intenational Econtonics, vol. 69, no. 1, pp. 64-83.

Akerlot, G. (2002) "Behavioral Mactoeconomics and Macroeconomic Behavios," 2001 Nobel Prize Lecture, in Les Prix Nobel: The Nobel Prizes 2001, edited by Tore Frängsmyr. The Nobel Foundation.

Baker, D. (2010) "The Myth of Expansionaty Fiscal Austerity," report of the Center for Economic Policy Research, October. Available ontine at http:/www.cepr.net/documents/publications/atsterity-myth-2010-10.pdf (accessed on March 5, 2014).

Borensztein, E. and Panizza, U. (2008) "The Costs of Sovereign Default," IMF Working Baper 238. Available at http:/www.imf org/external/pubs/tt/wp/2008/wp08238. (accessed October 24,2012 ).
Barr, D., Bush, O, and Pienkowski, A. (2014) "GDP-linked Ronds and Sovereign Default," in Joseph E. Stiglitz and Daniel Heymann (eds), Life After Debt: The Origins and Resolutions of Debt Crisis, IEA Conference volume no. 152

Cass. D. and Shell, K. (1983) "Do Sunspots Mattet?" Iournal of Political Economy, vol. 91 no. 2, pp. 193-227.

Citizens' Commistion On Jobs, Deficits And Ametica's Economic Futute (2010) "Report of the Citizens' Commission On Jobs. Deficts And Amport instute for Americ's Future fites documents 11: Gati, D, Catlo 1 , "Mellh Gath, D, Galle Mobility Constraints, Productivity Trends, and Extended C Behavior \& Organization,

Delli Gatti, D., Gallegatl, M., Greenwald, B.C., Russo, A. and Stiglitz, J.E. (2012b) "Sectoral Imbalances and Long kun Crises," in F. Allen, M. Aoki, J.-17, Hitoussi, N. Kiyotaki,

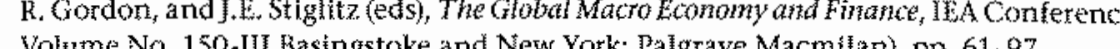

Volume No. 150-III Basingstoke and New York: Palgrave Macmilan), pp. $61-97$.
Diamond, D.W. and Dybvig, D.H. (1983) "Bank Runs, Deposit Insur'snce, and Liquidity," Fournal of Politicat Economy, vol, 91, no. 3, pp. 401-19.

Eaton, J. and Gersovitz, M. (1981) "Debt with Potential Repudiation: Theoretical and Empirical Analysis," Review of Econtomic Studies, vol. 48, no. 2, pp. 289-309.

Eaton, J., Gersovitz, M., and Stiglitz, J.R. (2013) "Pute Theory of Country Risk," European Economic Review, vol. 30, no. 3, pp. 481-513. (reprinted with commentary in J.E. Stiglitz, Selected Scientific Papers, V. II (New York and Oxford: Oxford University Press, 2013).

Fisher, 1. (1933) "The Debt Deflation Theory of Great Depressions," Econometrica, vol 1 no. 4, pp. 337-57.

Fuster, A., Laibson, D. and Mendel, B. (2010) "Natural Expectations and Macroeconomic Fluctuations," Journal of Economic Policy, vol. 24, no. 4, pp. 67-84.

Greenwald, B, and Stiglitz, J.E. (1988a) "Imperfect Information, Winance Constraint and Business Fluctuations," in M. Kohn and S.C. Tsiang (eds), Finantee Constraints, Expectations, and Macroeconomics (Oxford: Oxford University Press), pp. 103-40.

Greenwald, B. and Stiglitz, J.E. (1988b) "Money, Impetfect Information and Economic Fluctuations," in M. Kohn and S.C. Tsiang (eds), Finance Constraints, Expectations and Macroeconomics (Oxford: Oxford University Press),pp. 141-6.5

Greenwald, B. and Stiglitz, J.,. (1990) "Macroeconomic Models with Equity and Credit Rationing," in R.B. Hubbard (ed.), Asymmetric Information, Corporate Finance, and Investment (Chicago: University of Chicago Press), pp. 15-42.

Greenwald, B. and Stiglitz, J,E. (1993a) "Tinancial Market Imperfections and Business Cycles," Quarterly Tournal of Economics, vol. 108, no. 1, pp. 77-114.

Greenwald, B. and Stiglitz, J.E. (1993b) "New and Old Keynesians," Journal of Economic Perspectives, vol. 7, no. 1, pp. 23-44.

Greenwald, B. and Stiglitz, J.E. (2003) Towards a New Paradiym in Monetary Econonics (Cambridge: Cambridge University Press).

Greenwald, B., Stiglitz, J.E., and Weiss, A. (1984) "Informational himperfections in the Capital Market and Macroecononic Fluctuations," American Economic Review, vol. 74, no. 2, pp. 194-9.

Griffith-Jones, Stephany (2014) "From Austerity to Growth in Europe: Some Lessons from Latin America, in Joseph E. Stiglitz and Daniel Heymann (edsy, Life After Debt. The Origins and Resolutions of Debt Crisis, IEA Conference volume no. 152. 
Guesnerie, R. (2001) Assessing Rational Expectations: Sunspot Multiplicity and Economic Fututuations (Cambridge, MA: MTT Press).

Whn, 1. (1966) "Equllibrium Dynamics with Heterogeneous Capital Goods," Quarterly youtnal of Economics, vol. 80, no. 4, pp. 633-46.

MF (2010) World Economic Outlook: Recovery, Risk, and Rebatancing (Washington, DC: IMF)

ayadev, A. and Konczal, M. (2010) "The boon not the Slump: The Right Time for Austerity," report of The Roosevelt Institute, August 23. Avallable online at thttp:/? Www.rooseveitinstitute.org/sites/all/files/not the_time_for_austerity.pdf (accessed October 1, 2013).

Jeanne, $\mathrm{O}$. and Korinek, A. (2012) "Managing Credit Booms and Busts: A pigouvian Taxation Approach," NBER Working Paper no. 16377. Available at http://www.nber. org/papers/w16377.pd (accessed October 2012)

Kindleberger, C. (1978) Manias, Pantics, and Crashes: A History of Financial Crises (New York: Basic Books).

Koo, R. (2008) The Holy Grail of Macroeconomics: Lessons from Japan's Great Recession (Singapore: John Wiley \& Sons).

Koo, R. (2010) "The Age of Balance Sheet Recessions: What post-2008 U.S., Furope and China Canl Leam from Japan 1990 2005" presentation given to the Institute of New Economic Thinking at King's College, Aptil 8. Available at http//ineteconominew sites/inetcivicactions net/files/NETOS-KOopresentation_0.pdf (accessed October 22 2012).

Lin, Justin Yifu (2012) New Structural Economies: A Framework for Rethinking Developmient Policies (Washington, DC: The World Bank).

Miller, Marcus and Lei Zhang (2013) "Saving the Euro: Self-fulfilling Crisis and the "Draghi Put'" in Joseph E. Stiplitz and Daniel Hoy

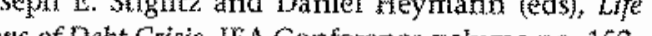

Miller, M. and Stiglitz, J.E. (2010) "Leverage and Asset Bubbles: Averting Armageddon with Chapter 11?," Economic Journal, vol. 120, no. 544, pp. 500-18. (Revision of "Bankruptcy protection against macroeconomic shocks: the case for a 'super chapter 11:" World Barak Conference on Capital Flows, Financial Crises, and Policies, April $15,1999$.

Minsky, H.P. (1982) Can "ft" Happen Again?? Essays on Instability and Finance (Armonk, NY: M.E. Sharpe)

Mundell, R. (1961) "A Theory of Optimum Cutrency Areas" The American Economic Review, vol. 51, no. 4, pp. $657 \ldots 65$.

Neary, P. and J. E. Stiglitz, 1982, "Expectations, Asset Accumulation and the Real-balance Effect," presented at Dublin Meetings of the Econometric Society, Septernber 1982, Working paper 1990

Neary, P. (1983) "Toward a Reconstruction of Keynesian Economics: Expectations and Constrained Equilibria," Quarterly lournal of Economics, 98, Supplement, pp. 199-228. Fszag, 1.R. and Stiglitz, J.E. (2002) "Optimal Fire Departments: Evaluating Bublic Policy in the Face of Externalities," The Brookings Institution, Jan. 4, 2002. Available online at http:/www2.gsb.columbia.edu/faculty/[stiglitz/download/papers/2002_Optimal Fire_Depts.pdf

Reinhart, C.M. and Rogoff, K. (2009) This Time is Different: Eight Centuries of Finansial Folly (Princeton, N]: Princeton University Press).

Oubini, Nouriel, 2008, "Will the Bretton Woods 2 (BW2) Regime Collapse Like the Original Bretton Woods Regime Did? The Coming End Gatme of BW2," RGE Monitor,
July 6. Available online at httpt/www.roubini.con/analysis/pdt/BW2, REGIME ORIG.pdf (accessed October 22, 2012).

Sandleris, Guido, "costs of Default," this rolume.

Shell, K. and Stiglitz, J,E. (1967) "The Allocation of Investment in a Dynamic Economy," Quatterty Journat of Economics, vol. 81, no. 4, pp. 592-609.

Stiglitz, J.E. (1977) "Theory of Local Public Goods," in M.S. Feldstein and R.P. Inman (eds), The Economics of Public Services (London: Macnillan Press), pp. 274-333. (Paper presented to IEA Conference, Turin, 1974.

Stiglitz, J.E. (1983a) "The Theory of local F'ublic Goods Twenty-Five Years After Tiebout: A Petspective," in G.R. Zodtow (ed.), Local Provision of Public Services: The Tiebout Model After Twenty-Five Years (New York: Academik Press), pp. 17 \$3.

Stiglitz, , E. (1983b) "Public Goods in Open Economies with Heterogeneous Individuals," in J.F. Thisse and H.G. Zoller (eds), Locational Analysis of Public Facilities (Amsterdam: North-Holland, 1983), pp. 55-78.

Stiglitz, J.E. (2000) "Some Elementary Principles of Bankruptcy," in Governance, Equity and Global Markets: Proceedings from the Annual Bank Conference on Development Economics in Europe, fune 1999 (Paris: Conseil d'Analyse economique), pp. 605-20.

Stiglitz, J.E. (2002) Globalization and its Discontents (New York: W.W. Norton).

Stiglitz, J.E. (2008) "Rational Expectations, Wobbly Growth, and Monetary Policy," working paper, Columbia University.

Stiglitz, J.E. (2010a) Freefall (New York: W.W. Norton

Stiglitz J (2010b) "Sovereign Debt: Notes on Theoretical Prameworks and Policy Analyses, in B. Herman, J.A. Ocampo, and S. Spiegel (eds), Overcoming Developing Cowntry Debt Crises (Oxford: Oxford University Press), pp. 35-69.

Com to Repair It," fournal of the European Economic Association, vol, 9, no. 4, pp. 591-645.

fournal of (2012) The Price of Ineguality (New York, W.W. Notton) (Spanish edition published by Taurus).

published by Taurus); Syieget, S., Ffrench-Davis, R. and Nayyar, D. (2006) Stabitity with Gou Dialogue Seties (Oxford: Oxford University Ptess).

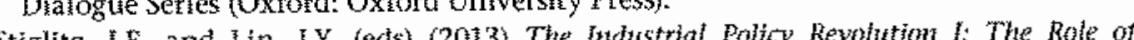
Stiglitz, J.E. and Lin, J.Y. (eds) (2013) The Mn whal Pow: Palgtowe Macmillan).

Goven Jent Bey Stiglitz, J.E. and Lin, J.Y. (eds) (2013) The Industrial Policy Revou
Century (Basingstoke and New York: Palgrave Macmillan).

Century (Basingstoke and New York: Palgrave Macminn). Utives: Why CDP Doesu't Add Up (New York: The New Press).

Stiglitz (2012) "The One Housing Solution Left: Mass Mortgage Stiglitz, J.E. and Zandi, M. (2012) "The One Housing Solution Left: Mass Mortgage
Financing," New York Times, August 12 . Avaliable at hitp:/www.nytimes. com/2012/08/13/opinion/the-one-housing-solution-left-mass-mortgage-tefinancing.
html (accessed Octobes 2, 2013).

UN Commission of Experts (2010) The Stightz Report: Reforming the International Monetary and Financial Systems in the Wake of the Global Crisis, with Members of the Commission of Experts of the President of the United Nations General Assembly on Retorms of th international Monetary and Financial System (New York: The New Press).

Wolf, M. (2008) Fixing Global Futance (Baltimore, MD: Johus Hopkins University press). 